\title{
Clarification of the relationship between the members of the family Thermomonosporaceae on the basis of 165 rDNA, 16S-23S rRNA internal transcribed spacer and 235 rDNA sequences and chemotaxonomic analyses
}

\author{
Zhenshui Zhang, ${ }^{1}$ Takuji Kudo, ${ }^{2}$ Yuki Nakajima ${ }^{2}$ and Yue Wang ${ }^{1}$ \\ Author for correspondence: Yue Wang. Tel: +65 7783207. Fax: +65 7791117. \\ e-mail: mcbwangy@imcb.nus.edu.sg
}

1 Microbial Collection and Screening Laboratory, Institute of Molecular and Cell Biology, National University of Singapore, 30 Medical Drive, Singapore 117609

2 Japan Collection of Microorganisms, RIKEN (The Institute of Physical and Chemical Research), 2-1 Hirosawa, Wako-shi, Saitama, 351-0198 Japan

\begin{abstract}
To resolve relationships between members of the family Thermomonosporaceae, phylogenetic analyses using three sets of nucleotide sequences from 16S rDNA, 235 rDNA and the 16S-23S internal transcribed spacer (ITS) were carried out. Nearly all species of the family were included in this study. On the basis of congruous phylogenetic results and chemotaxonomic data, the following proposals are made. First, Actinomadura libanotica, Actinomadura aurantiaca, Actinomadura glomerata and Actinomadura longicatena are transferred to the genus Actinocorallia as Actinocorallia libanotica comb. nov., Actinocorallia aurantiaca comb. nov., Actinocorallia glomerata comb. nov. and Actinocorallia longicatena comb. nov., respectively. All the species of this genus are phylogenetically coherent and of phospholipid type PII (presence of phosphatidylethanolamine), distinguishing them from other Actinomadura species that are of phospholipid type PI (absence of diagnostic phospholipids). Second, Excellospora viridilutea is transferred to the genus Actinomadura as Actinomadura viridilutea comb. nov. As a result of the proposed transfers, the family Thermomonosporaceae now contains four genera Thermomonospora, Actinomadura, Actinocorallia and Spirillospora. The genus Actinocorallia and family Thermomonosporaceae are redescribed.
\end{abstract}

Keywords: Thermomonosporaceae, Actinomadura, Actinocorallia, Excellospora, phylogeny

\section{INTRODUCTION}

In a previous $16 \mathrm{~S}$ rDNA sequence-based phylogenetic analysis of the members of the family Thermomonosporaceae, it was observed that Thermomonospora curvata, Excellospora viridilutea, Actinocorallia herbida and Spirillospora albida were intermixed with Actinomadura species in a clade distantly separated from their phylogenetic neighbours, the members of the families Streptosporangiaceae and Nocardiopsiaceae

Abbreviations: DPG, diphosphatidylglycerol; ITS, internal transcribed spacer; PE, phosphatidylethanolamine; PI, phosphatidylinositol; PIM, phosphatidylinositol mannoside.

The GenBank accession numbers for the 16S rDNA, 16S-23S rDNA ITS and $23 \mathrm{~S}$ rDNA sequences of members of the family Thermomonosporaceae are given in Table 1.
(Zhang et al., 1998). This intermixing causes confusion in the taxonomic positions of and relationships between members of five actinomycete genera, raising the necessity of further investigation. The close relatedness of Thermomonospora curvata, Excellospora viridilutea, Actinocorallia herbida and Spirillospora albida with Actinomadura species has also been noticed in some earlier studies on the basis of phylogenetic and chemotaxonomic results (Goodfellow, 1992; Kroppenstedt \& Goodfellow, 1992; Zhang et al., 1998). However, no transfer has been proposed, largely because each of the four species exhibits some features that appear to justify their independent genus status.

Thermomonospora was proposed by Henssen in 1957 for thermophilic actinomycete strains characterized by the formation of single spores on aerial mycelium. 
After recent reclassification of the genus Thermomonospora (Zhang et al., 1998), the type species Thermomonospora curvata and Thermomonospora chromogena are now the only two members left in this genus. Thermomonospora curvata seems to have the closest phylogenetic relatedness with Actinomadura echinospora (Zhang et al., 1998). However, this relationship is not conclusive due to the lack of significant bootstrap value support. Thermomonospora chromogena has been recently found to contain two distinct types of rRNA operons which renders its phylogenetic relationships with other actinomycetes uncertain (Yap et al., 1999). However, it is quite certain that Thermomonospora chromogena is located outside of the family Thermomonosporaceae (Zhang et al., 1998; Yap et al., 1999).

The genus Excellospora was introduced to accommodate three thermophilic species (Agre \& Guzeva, 1975). The type species Excellospora viridilutea was cited in the Approved Lists of Bacterial Names (Skerman et al., 1980), while the other two species 'Excellospora rubrobrunea' and 'Excellospora viridinigra' were considered invalid. Previous studies by several groups of researchers showed that 'Excellospora rubrobrunea' and 'Excellospora viridinigra' had many properties in common both with one another and with Actinomadura madurae and related strains (Greiner-Mai et al., 1987; Meyer, 1989; Kroppenstedt et al., 1990). The two species were, therefore, transferred to the genus Actinomadura as Actinomadura rubrobrunea (Kroppenstedt et al., 1990). Currently, the only chemotaxonomic property used to distinguish Excellospora viridilutea from Actinomadura species is the presence in Excellospora strains of higher amounts of branched fatty acids, particularly iso-17:0, and lower amounts of 10-methyl acids than in typical Actinomadura strains. However, it is rather puzzling that although the three Excellospora species share similar fatty acid profiles among many other properties, 'Excellospora rubrobrunea' and 'Excellospora viridinigra', but not the type species Excellospora viridilutea, were transferred to Actinomadura. In the $16 \mathrm{~S}$ rDNA tree, Excellospora viridilutea is located among Actinomadura species (Zhang et al., 1998). Thus, the taxonomic position of Excellospora viridilutea is questionable and needs further clarification.

In 1963, Couch proposed the genus Spirillospora. Bearing a sporangium-like structure similar to that of Streptosporangium, Spirillospora was temporarily placed in the family Streptosporangiaceae (Goodfellow, 1992). Chemotaxonomic data showed that the type species Spirillospora albida (type strain ATCC $15331^{\mathrm{T}}=\mathrm{JCM} 3041^{\mathrm{T}}$ ) is more similar to Actinomadura species in the profiles of phospholipids, predominant menaquinones and fatty acids than to Streptosporangium species (Goodfellow, 1992; Kroppenstedt \& Goodfellow, 1992). Spirillospora albida was found to be very closely related to some Actinomadura species in the 16S rDNA tree (Zhang et al., 1998). Despite all the similarities to Actinomadura species, Spirillospora species are characterized by having a unique property, the formation of sporangia containing motile spores.

The genus Actinocorallia herbida was proposed by Iinuma et al. (1994). This genus is characterized by cell wall type III/C (containing meso-diaminopimelic acid without diagnostic sugar) and the growth of unique coralloid sporophores arising from the substrate mycelia; on the tips of the sporophores long chains of non-motile spores are borne. In the $16 \mathrm{~S}$ rDNA tree Actinocorallia herbida was found to aggregate tightly with Actinomadura aurantiaca and Actinomadura libanotica forming a clade distant from the one containing the rest of the Actinomadura species, Thermomonospora curvata, Excellospora viridilutea and Spirillospora albida. Interestingly, Actinomadura libanotica grows synnemata (Meyer, 1979), sporebearing structures resembling those formed by Actinocorallia herbida, but Actinomadura aurantiaca does not form a similar structure (Lavrova \& Preobrazhenskaya, 1975). Thus, the question arises whether Actinocorallia herbida should be a member of Actinomadura or whether the two Actinomadura species should be transferred to the genus Actinocorallia.

16S rDNA sequences have been used extensively in determining phylogenetic relationships between organisms (Woese, 1987; Woese et al., 1990; Amann et al., 1995). Due to their highly conserved nature, closely related organisms are often found to have nearly identical 16S rRNA gene sequences (Stackebrandt \& Goebel, 1994), limiting its power in resolving close relationships. One solution to this problem is to use other evolutionarily conserved genes, such as $23 \mathrm{~S}$ rRNA genes. Congruity of the results obtained from using multiple gene sets will provide more reliable data for inferring organismal relationships. Analysis of genes or DNA sequences exhibiting faster evolution rates, such as the internal transcribed spacers (ITSs) of rRNA operons, is also of important value in elucidating close relationships (Gurtler \& Stanisich, 1996; Zhang et al., 1997).

In this study, we conducted phylogenetic analyses using DNA sequences of $16 \mathrm{~S}$ and $23 \mathrm{~S}$ rDNA and $16 \mathrm{~S}-23 \mathrm{~S}$ rRNA gene spacers to further investigate the phylogenetic positions of Thermomonospora curvata, Excellospora viridilutea, Actinocorallia herbida and Spirillospora species and their relationships with Actinomadura species.

\section{METHODS}

Organisms and culture conditions. The actinomycete strains used in this study were purchased from ATCC (American Type Culture Collection, Manassas, VA, USA), IFO (Institute for Fermentation, Osaka, Japan), DSM (Deutsche Sammlung von Mikroorganismen und Zellkulturen $\mathrm{GmbH}$, Braunschweig, Germany) and JCM (Japan Collection of Microorganisms, Wako, Japan). Strain names and GenBank 
Table 1 Actinomycete species used in this study

Only accession numbers for sequences determined in this study are given.

\begin{tabular}{|c|c|c|c|c|}
\hline \multirow[t]{2}{*}{ Species } & \multirow[t]{2}{*}{ Source } & \multicolumn{3}{|c|}{ GenBank accession no. } \\
\hline & & $16 S$ & ITS & 23S \\
\hline Actinocorallia herbida & IFO $15485^{\mathrm{T}}$ & & AF134109 & AF134086 \\
\hline Actinomadura atramentaria & IFO $14695^{\mathrm{T}}$ & & AF134089 & AF134071 \\
\hline Actinomadura aurantiaca & $\mathrm{JCM} 8201^{\mathrm{T}}$ & AF134066 & AF 134090 & AF134072 \\
\hline Actinomadura citrea & IFO $14678^{\mathrm{T}}$ & & AF134091 & \\
\hline Actinomadura coerulea & JCM $3320^{\mathrm{T}}$ & & AF134092 & \\
\hline Actinomadura cremea subsp. cremea & $\mathrm{JCM} 3308^{\mathrm{T}}$ & AF134067 & AF134094 & AF134073 \\
\hline Actinomadura cremea subsp. rifamycini & IFO $14183^{\mathrm{T}}$ & & AF134093 & AF134074 \\
\hline Actinomadura echinospora & IFO $14042^{\mathrm{T}}$ & & AF134095 & AF 134075 \\
\hline Actinomadura fibrosa & ATCC $49459^{\mathrm{T}}$ & AF163114 & AF163125 & AF163136 \\
\hline Actinomadura formosensis & $\mathrm{JCM} 7474^{\mathrm{T}}$ & & AF134096 & \\
\hline Actinomadura fulvescens & IFO $14347^{\mathrm{T}}$ & & AF134097 & AF134076 \\
\hline Actinomadura glomerata & $\mathrm{JCM} 9376^{\mathrm{T}}$ & AF134068 & AF134098 & AF134077 \\
\hline Actinomadura hibisca & $\mathrm{JCM} 9627^{\mathrm{T}}$ & AF 163115 & AF163126 & AF163137 \\
\hline Actinomadura kijaniata & $\mathrm{JCM} 3306^{\mathrm{T}}$ & & AF134099 & \\
\hline Actinomadura libanotica & IFO $14095^{\mathrm{T}}$ & & AF134100 & AF134078 \\
\hline Actinomadura livida & $\mathrm{JCM} 3387^{\mathrm{T}}$ & AF163116 & AF163127 & AF163138 \\
\hline Actinomadura longicatena & $\mathrm{JCM} 9377^{\mathrm{T}}$ & AF163117 & AF163128 & AF163139 \\
\hline Actinomadura luteofluorescens & IFO $13057^{\mathrm{T}}$ & & AF134101 & AF134079 \\
\hline Actinomadura macra & IFO $14102^{\mathrm{T}}$ & & AF134102 & AF 134080 \\
\hline Actinomadura madurae & JCM $7436^{\mathrm{T}}$ & & AF134103 & \\
\hline Actinomadura oligospora & ATCC $43269^{\mathrm{T}}$ & AF163118 & AF163129 & AF 163140 \\
\hline Actinomadura pelletieri & $\mathrm{JCM} 3388^{\mathrm{T}}$ & AF163119 & AF163130 & AF163141 \\
\hline Actinomadura rubrobrunea & IFO 14622 & AF134069 & AF134104 & AF134081 \\
\hline Actinomadura rugatobispora & IFO $14382^{\mathrm{T}}$ & & AF134105 & AF134082 \\
\hline Actinomadura spadix & $\mathrm{JCM} 3146^{\mathrm{T}}$ & AF 163120 & AF163131 & AF163142 \\
\hline Actinomadura umbrina & $\mathrm{JCM} 6837^{\mathrm{T}}$ & AF163121 & AF163132 & AF163143 \\
\hline Actinomadura verrucosospora & IFO $14100^{\mathrm{T}}$ & & AF134106 & AF134083 \\
\hline Actinomadura vinacea & $\mathrm{JCM} 3325^{\mathrm{T}}$ & AF134070 & AF134107 & AF134084 \\
\hline Actinomadura viridis & $\mathrm{JCM} 3112^{\mathrm{T}}$ & & AF134108 & AF134085 \\
\hline Actinomadura yumaensis & $\mathrm{JCM} 3369^{\mathrm{T}}$ & AF163122 & AF163133 & AF163144 \\
\hline Excellospora viridilutea & JCM $3398^{\mathrm{T}}$ & & AF134110 & AF134087 \\
\hline Spirillospora albida & $\mathrm{JCM} 3041^{\mathrm{T}}$ & & AF134111 & AF134088 \\
\hline Spirillospora rubra & $\mathrm{JCM} 6875^{\mathrm{T}}$ & AF163123 & AF163134 & AF163145 \\
\hline Spirillospora sp. & $\mathrm{JCM} 3123^{\mathrm{T}}$ & AF163124 & AF163135 & AF163146 \\
\hline Thermomonospora curvata & JCM $3096^{\mathrm{T}}$ & & AF134112 & \\
\hline
\end{tabular}

nucleotide sequence accession numbers are listed in Table 1. For the preparation of genomic DNA, the cells were grown in Bennett's medium (Atlas, 1993) to exponential phase. For the phospholipid and fatty acid analyses, the cells were grown to late exponential phase in glucose yeast extract medium $(10 \mathrm{~g}$ yeast extract, $10 \mathrm{~g}$ D-glucose in 11 distilled water, $\mathrm{pH} 7 \cdot 2)$.

Preparation of genomic DNAs. The genomic DNA of the actinomycetes was prepared as described previously (Wang et al., 1996).

PCR amplification, cloning and sequencing. The PCR amplification, cloning and sequencing of $16 \mathrm{~S}$ rDNAs were done as described previously (Wang et al., 1996). The 16S-23S rRNA gene spacer and the $5^{\prime}$ one-third of the $23 \mathrm{~S}$ rRNA genes were amplified by PCR using a pair of primers, one targeting a conserved region at the end of the $16 \mathrm{~S}$ rRNA gene and the other a conserved block within the 23S rRNA gene. The sequences of the two oligonucleotides were as follows: 5'-GGTTGGATCCACCTCCTT-3', corresponding to nt 1525-1542 (Escherichia coli 16S rRNA gene numbering; Brosius et al., 1978), and 5'-ACCAGTGAGCTATTAGCG-3' (nt 1090-1107). After cloning of the PCR products, the M13 forward and reverse universal primers were used for sequencing the ends of each clone. The internal regions were sequenced in both orientations by using the following two sets of oligonucleotide primers targeting two conserved sequences within $23 \mathrm{~S}$ rDNA. The first set of primers targeting nt 45-60 (Escherichia coli 23S rRNA gene numbering) were 23S-40f (5'-CCGATGAAGGACGTGGGA-3') and 23S-40r (5'-TCCCACGTCCTTCATCGG-3'), and the second set of primers targeting nt 456-472 were $23 \mathrm{~S}$ 460f (5'-CCTTTCCCTCACGGTACT-3') and 23S-460r (5'AGTACCGTGAGGGAAAGG-3'). Being aware of 
possible existence of sequence heterogeneity between different copies of rRNA operons (Clayton et al., 1995; Wang et al., 1997; Yap et al., 1999), we picked three clones from each PCR reaction for sequence analysis. Only low levels of heterogeneity $(<1 \%)$ were observed between different clones from a few organisms and the heterogeneity had no effect on the results of phylogenetic analysis.

Sequence alignment and phylogenetic analysis. Multiple sequence alignment and computation of sequence similarities were carried out by using the CLUSTAL method of the DNASTAR program (Madison, WI, USA). The sequence alignments were also verified according to the consensus secondary structures of the $16 \mathrm{~S}$ and $23 \mathrm{~S}$ rRNA molecules (Gutell et al., 1994). Evolutionary distance matrices were generated by the method of Jukes \& Cantor (1969). Phylogenetic trees were constructed by using both the neighbour-joining method of Saitou \& Nei (1987) and the maximum-parsimony method (Swofford \& Begle, 1993). The confidence level of phylogenetic tree topology was evaluated by using the bootstrap method (Felsenstein, 1985). The software for the bootstrap analysis is contained in the CLUSTAL V phylogenetic analysis software package (Higgins, 1992).

Chemotaxonomic analyses. Phospholipids were analysed by the method of Minnikin et al. (1984). Cellular fatty acid methyl esters were prepared by the direct transmethylation method with methanolic hydrochloride and analysed by GLC as described by Suzuki \& Komagata (1983). Samples for the analysis of whole-cell sugars were prepared as described by Lechevalier \& Lechevalier (1970) and the composition was determined by using the HPLC method of Mikami \& Ishida (1983).

\section{RESULTS}

To get a more complete representation of species belonging to the family Thermomosporaceae, we included in this study all the Actinomadura species listed in Bergey's Manual of Determinative Bacteriology (Holt et al., 1994), two new Actinomadura species, Actinomadura glomerata and Actinomadura longicatena (Itoh et al., 1995), Spirillospora albida, Spirillospora rubra, an undefined Spirillospora strain, JCM $3123^{\mathrm{T}}$, Excellospora viridilutea and Thermomonospora curvata (Table 1). We obtained the 16S rDNA sequences from all the species which were not included in the previous study. We also determined the sequences of approximately $1.2 \mathrm{~kb}$ of the $5^{\prime}$ end of $23 \mathrm{~S}$ rDNAs and the $16 \mathrm{~S}-23 \mathrm{~S}$ rRNA gene spacers.

\section{Analysis of 16S rDNA sequences}

A pairwise comparison of almost complete $16 \mathrm{~S}$ rDNA sequences (nt 59-1491 and data not shown) shows that Excellospora viridilutea is $99.5 \%$ identical to Actinomadura rubrobrunea which was previously a member of the genus Excellospora (Kroppenstedt et al., 1990), indicating their close relationship. Spirillospora albida exhibits highest similarity $(97 \cdot 5 \%)$ with Spirillospora strain JCM $3123^{\mathrm{T}}$; however, Spirillospora rubra shares about $94 \%$ similarity with Spirillospora albida and strain JCM $3123^{\mathrm{T}}$, a level lower than its similarity to several Actinomadura species. Thermomonospora curvata displays highest similarity to Actinomadura umbrina $(94.2 \%)$ and a mean of $91.6 \%$ similarity (ranging from 90.3 to $93.2 \%$ ) to all other species of the family Thermomonosporaceae.

Phylogenetic trees were reconstructed using the $16 \mathrm{~S}$ rDNA sequences. The application of both the neighbour-joining and the maximum-parsimony methods and the change of outgroups produced nearly identical tree topology relating the members of the family Thermomonosporaceae. Fig. 1(a) shows a representative tree constructed using the neighbourjoining method. Within the clade of Thermomonosporaceae, intermixing of members from different genera is again demonstrated and some new relationships also emerge which were not observed previously. The three Spirillospora sequences fail to form one clade. Although Spirillospora albida and Spirillospora strain JCM $3123^{\mathrm{T}}$ aggregate tightly, they are distantly related to Spirillospora rubra and located among Actinomadura species. Excellospora viridilutea exhibits the closest relatedness with Actinomadura rubrobrunea. The clade containing the two species is also placed among Actinomadura species. Four Actinomadura species, Actinomadura libanotica, Actinomadura aurantiaca, Actinomadura glomerata and Actinomadura longicatena, form a very stable clade (bootstrap value 999) with Actinocorallia herbida. This clade is separated from the one containing the rest of the Actinomadura species except Actinomadura spadix that stands alone and is distantly related to all other members of the family Thermomonosporaceae. Thermomonospora curvata aggregates with Actinomadura echinospora and Actinomadura umbrina forming a clade separated from other Actinomadura species. However, this clade is supported by a low bootstrap value of 337 .

\section{Analysis of 235 rDNA sequences}

It is interesting to note that the similarity values scored between the different 23S rDNA sequences [ $\sim 1200$ bases corresponding to nt 1-1108 (Escherichia coli numbering)] are on average $2 \%$ lower than those between 16S rDNA sequences, indicating that this region of 23S rRNA genes has evolved faster than the 16S rRNA genes. The result of the pairwise sequence comparison is largely the same as that of the $16 \mathrm{~S}$ rDNA sequence analysis. Excellospora viridilutea was again found to share with Actinomadura rubrobrunea the highest sequence similarity of $96 \%$. The sequences of Spirillospora albida and Spirillospora strain JCM $3123^{\mathrm{T}}$, which share $95.4 \%$ similarity to each other, show only 92.7 and $92.8 \%$ similarity, respectively, to the sequence of Spirillospora rubra, a level lower than their relatedness with many Actinomadura species. Thermomonospora curvata exhibits 92.4 and $91.3 \%$ sequence similarity to Actinomadura echinospora and Actinomadura umbrina, respectively, and less than 90.5\% to all other Actinomadura species.

The 23S rDNA sequences were used to reconstruct phylogenetic trees by both neighbour-joining and 
(a)

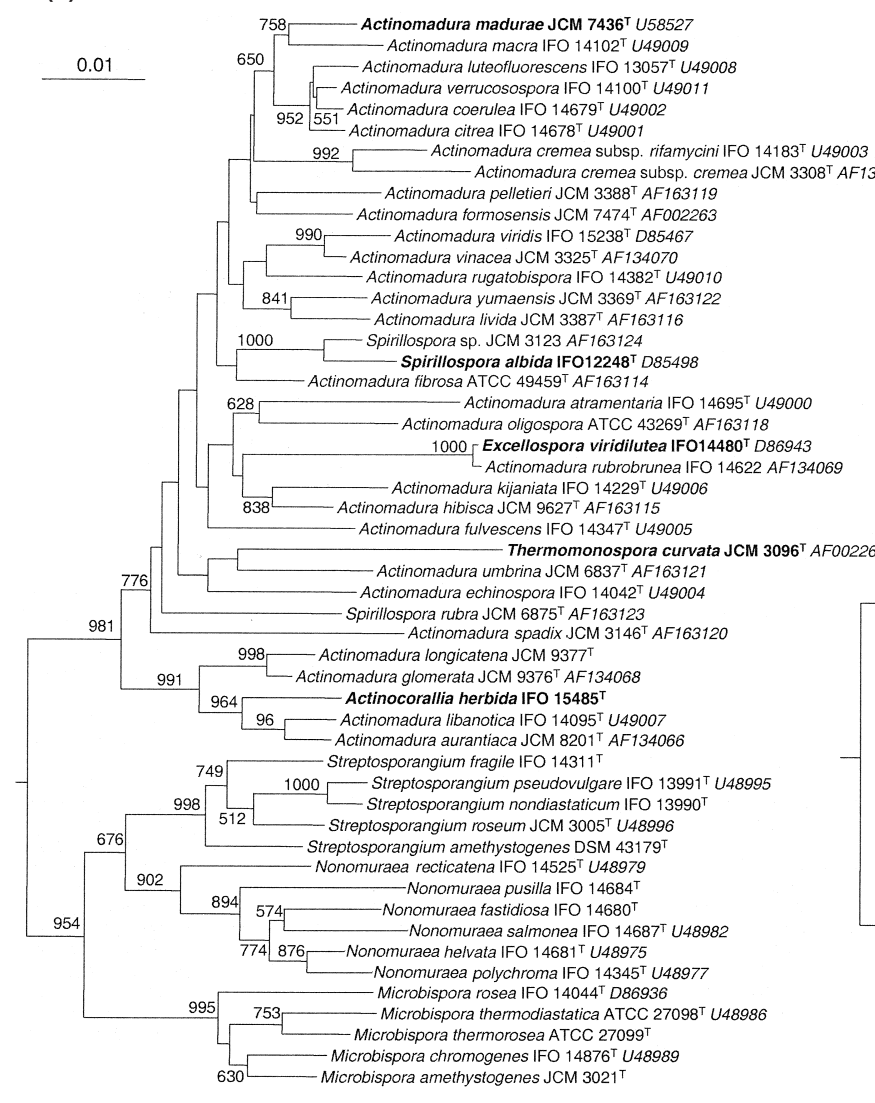

(b)

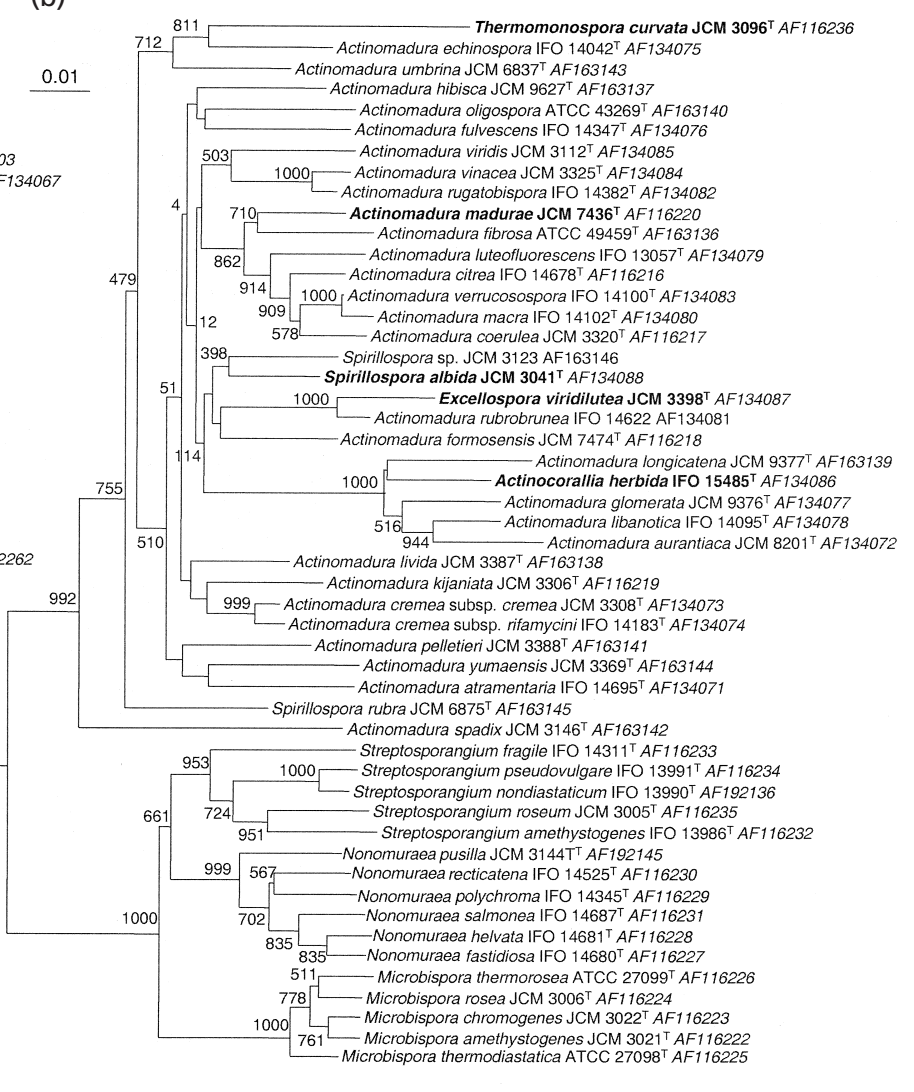

Fig. 1. Neighbour-joining trees reconstructed by using $16 \mathrm{~S}$ (a) and $23 \mathrm{~S}$ (b) rDNA sequences. The regions from nt 56 to 1491 (Escherichia coli numbering) and from 1 to 1108 were used for constructing the 16S and 23S rDNA trees, respectively. Small regions with alignment ambiguities were excluded, i.e. nt 181-220, 453-481, $1007-1040$ and 1133-1141 for the 16S rDNA sequences and 256-320, 348-358, 539-552 and 651-655 for the 23S rDNA sequences. Both trees were rooted by using the corresponding rDNA sequences of Streptomyces coelicolor A3(2) (GenBank accession no. AL079345). The numbers at the nodes are bootstrap values based on 1000 resamplings. Bootstrap values lower than 500 are not shown except a few very low values on the 235 rDNA tree to show the unreliable relationship between Actinomadura species of the clade containing Actinocorallia herbida and four Actinomadura species. The bars represent the number of inferred substitutions per $1000 \mathrm{nt}$. All the sequences determined in this study are listed in Table 1 and the rest of the sequences were retrieved from the GenBank and EMBL databases.

maximum-parsimony methods. The relationships described below were produced on both trees and Fig. 1(b) shows the neighbour-joining tree only. The relationships revealed in this tree are in good accord with those shown by the $16 \mathrm{~S}$ rDNA tree in the following aspects. First, Excellospora viridilutea and Actinomadura rubrobrunea aggregate tightly. Second, Thermomonospora curvata, Actinomadura echinospora and Actinomadura umbrina form a fairly stable clade (bootstrap value 636) which is separated from the one containing the rest of the Actinomadura species except Actinomadura spadix which again shows a distant relationship to all other members of the family. Third, the tight clustering of Actinocorallia herbida with four Actinomadura species, Actinomadura libanotica, Actinomadura aurantiaca, Actinomadura glomerata and Actinomadura longicatena, is reproduced, even though the clade is located among Actinomadura species. However, this clade has a long branch and its location is not certain because all the higher level clades have very low bootstrap values. The tight aggregation of these species was not affected by the use of different outgroups, though the location of this clade may change. Fourth, the three Spirillospora strains do not form one clade, and Spirillospora rubra is distantly related to Spirillospora albida and strain JCM $3123^{\mathrm{T}}$.

\section{Analysis of 16S-23S rRNA ITS sequences}

We sequenced three clones of the ITS from each organism and did not find significant heterogeneity. No tRNA gene was found in any of the spacer sequences. The lengths of the $16 \mathrm{~S}-23 \mathrm{~S}$ rDNA spacers of Actinocorallia herbida, Actinomadura libanotica, Actinomadura aurantiaca, Actinomadura glomerata and Actinomadura longicatena are similar, being 403, $385,374,381$ and $385 \mathrm{bp}$, respectively. The spacer sizes of the rest of the Actinomadura species vary over a larger range from 387 to $553 \mathrm{bp}$. Due to the variations 


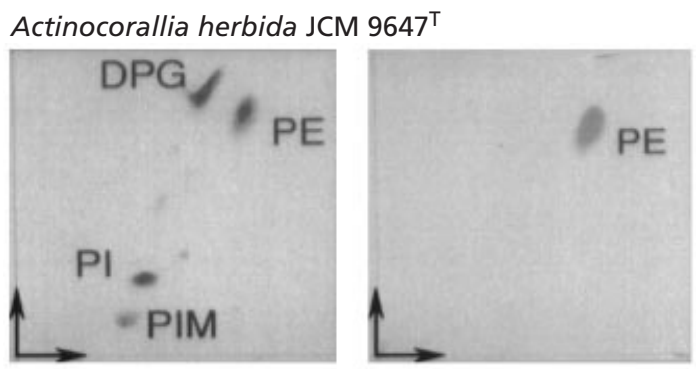

Actinomadura libanotica JCM $3284^{\top}$

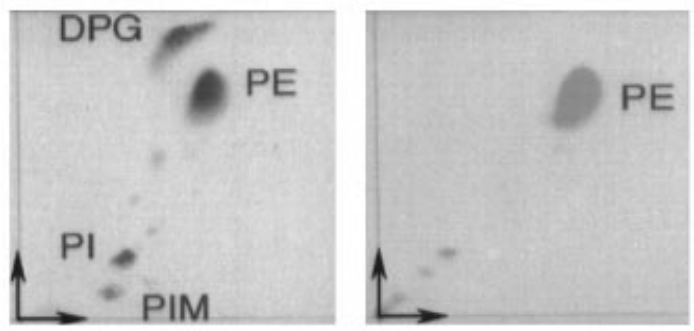

Spirillospora albida JCM $3041^{\top}$

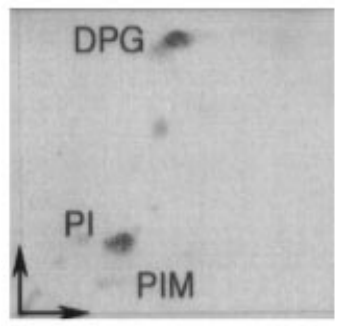

Dittmer \& Lester agent for all phospholipids

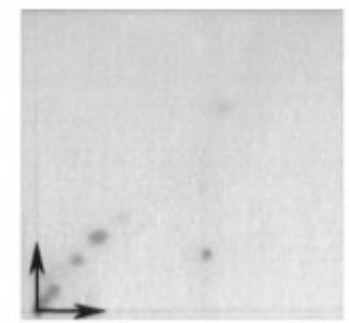

Ninhydrin reagent for free amino groups

Fig. 2. Thin-layer chromatograms of total phospholipids. The name of the actinomycete analysed is given above each pair of chromatograms. The reagents used for visualizing the phospholipids are indicated at the bottom of the figure.

in length between the spacers from different species, multiple sequence alignment is difficult. Nevertheless, a major part $(\sim 70 \%)$ of the sequences of the five Actinocorallia-related species can be aligned with limited ambiguity, which contains several blocks of sequences which are not present in the spacers of the rest of the Actinomadura species (alignment not shown). The levels of similarity between Actinocorallia herbida, Actinomadura libanotica, Actinomadura glomerata, Actinomadura longicatena and Actinomadura aurantiaca range from $47 \cdot 3$ to $62 \cdot 2 \%$ with a mean value of $53.5 \%$, which is markedly higher than the scores between these five species and the rest of the Actinomadura species ranging from 24 to $45.5 \%$ with a mean of $35 \%$. This result is in good accordance with the results of phylogenetic analyses above, suggesting close relatedness of these five species and their distance to other Actinomadura species. Excellospora viridilutea once again was found to share the highest sequence similarity $(79.5 \%)$ with Actinomadura rubrobrunea, which is considerably greater than the $30.5-59 \cdot 4 \%$ range recorded between these two species and other

Actinomadura species. Spirillospora albida and strain JCM $3123^{\mathrm{T}}$ exhibit about 70 and $50 \%$ sequence similarity with several Actinomadura species, respectively, and these values are much higher than those ( $<40 \%$ ) scored between many Actinomadura species. Spirillospora rubra exhibits only 30-40\% sequence similarity to all other species of the family.

\section{Re-examination of some chemotaxonomic properties of Actinocorallia herbida and Actinomadura libanotica}

We have observed that four Actinomadura species, Actinomadura libanotica, Actinomadura aurantiaca, Actinomadura glomerata and Actinomadura longicatena, consistently aggregate with Actinocorallia herbida forming one stable clade. Peculiarly, the phospholipid composition of all the species is of type PII, except that of Actinomadura libanotica which is of type PI (Kroppenstedt et al., 1990) like the rest of the Actinomadura species; the whole-cell hydrolysates of the four Actinomadura species contain the diagnostic sugar madurose which was not reported to be present in Actinocorallia herbida (Iinuma et al., 1994). It appears that this phylogenetically well-defined group is chemotaxonomically heterogeneous. To address the possibility that the phospholipid type of Actinomadura libanotica and sugar type of Actinocorallia herbida were wrongly determined in earlier studies, we reexamined the phospholipids and sugars of Actinomadura libanotica (strains JCM $3284^{\mathrm{T}}$ and DSM $43554^{\mathrm{T}}$ obtained from two culture collections) and Actinocorallia herbida. Figure 2 shows the detection in Actinomadura libanotica of major amounts of diphosphatidylglycerol (DPG), phosphatidylethanolamine (PE) and phosphatidylinositol (PI), components corresponding to phospholipid type PII, not type PI. We also detected the presence of madurose in Actinocorallia herbida (not shown). In addition, the description of the fatty acid composition of Actinocorallia herbida given by Iinuma et al. (1994) was not complete, lacking information about the branched and 10-methyl-branched fatty acids. To fill in the missing information, we analysed the fatty acids of Actinocorallia herbida and found that its fatty acid pattern is very similar to that exhibited by Actinomadura species (Table 2) which was defined as type 3 a (Kroppenstedt et al., 1990).

\section{DISCUSSION}

Several relationships among the members of Thermomonosporaceae were consistently demonstrated by the use of the three DNA sequence sets. First, Actinomadura libanotica, Actinomadura aurantiaca, Actinomadura glomerata and Actinomadura longicatena consistently aggregate with Actinocorallia herbida, forming a very stable clade in both the $16 \mathrm{~S}$ and $23 \mathrm{~S}$ rDNA phylogenetic trees. This clade is separated from another clade containing the rest of the Actinomadura 
Table 2 Cellular fatty acid composition

\begin{tabular}{|c|c|c|c|c|c|c|c|c|c|c|c|c|c|c|c|c|c|c|c|c|c|}
\hline \multirow[t]{3}{*}{ Organism* } & \multicolumn{20}{|c|}{ Fatty acid composition (\%) } & \multirow[t]{3}{*}{ Reference $\dagger$} \\
\hline & \multicolumn{9}{|c|}{ Normal } & \multicolumn{7}{|c|}{ Iso } & \multirow{2}{*}{$\frac{\text { Anteiso }}{17: 0}$} & \multicolumn{3}{|c|}{ 10-Methyl } & \\
\hline & $14: 0$ & $16: 0$ & $16: 1$ & 18:0 & 18:1 & $15: 0$ & 17:0 & $17: 1$ & 19:1 & $14: 0$ & $16: 0$ & $16: 1$ & $18: 0$ & $18: 1$ & $15: 0$ & 17:0 & & 10Me- & $\mathrm{OMe}$ & 0Me-18 & \\
\hline $\begin{array}{l}\text { Actinocorallia herbida } \\
\mathrm{JCM} 9647^{\mathrm{T}}\end{array}$ & 1 & 18 & 9 & 3 & 15 & 2 & 4 & 7 & 1 & 1 & 13 & 1 & 1 & 2 & TR & 1 & 1 & 3 & 3 & 10 & $\mathrm{a}$ \\
\hline (Actinocorallia herbida) & & 26 & 15 & 4 & 27 & 4 & 8 & 16 & & & & & & & & & & & & & $\mathrm{~b}$ \\
\hline $\begin{array}{l}\text { Actinomadura libanotica } \\
\text { JCM } 3284^{\mathrm{T}}\end{array}$ & 1 & 20 & 14 & 3 & 19 & 2 & 3 & 4 & 1 & $\mathrm{TR}$ & 8 & 1 & 1 & 2 & TR & 1 & 1 & 2 & 1 & 8 & $\mathrm{a}$ \\
\hline (Actinomadura libanotica) & 2 & 22 & 9 & 5 & 17 & 4 & 7 & 7 & & & 12 & & 1 & & 1 & 3 & 1 & 1 & 4 & 4 & $\mathrm{c}$ \\
\hline (Actinomadura aurantiaca) & 1 & 21 & 9 & 6 & 17 & 1 & 3 & 1 & & $\mathrm{TR}$ & 17 & 1 & 2 & & TR & 2 & 2 & 2 & 4 & 9 & $\mathrm{c}$ \\
\hline (Actinomadura glomerata) & 2 & 28 & 4 & 5 & 20 & 3 & 6 & & & & 9 & & & & & & 4 & & 2 & 15 & $\mathrm{~d}$ \\
\hline (Actinomadura longicatena) & 2 & 24 & 5 & 6 & 16 & 3 & 5 & & & & 13 & & & & & & 4 & & 2 & 14 & $\mathrm{~d}$ \\
\hline $\begin{array}{l}\text { Spirillospora albida } \\
\text { JCM } 3041^{\mathrm{T}}\end{array}$ & 3 & 24 & 3 & 3 & 21 & TR & TR & TR & & 1 & 11 & & 2 & 2 & & & & $\mathrm{TR}$ & TR & 21 & $\mathrm{a}$ \\
\hline Spirillospora sp. JCM $3123^{\mathrm{T}}$ & 3 & 26 & 2 & 5 & 27 & $\mathrm{TR}$ & 1 & 1 & & 1 & 10 & & 3 & 2 & & & & TR & 1 & 11 & $\mathrm{a}$ \\
\hline $\begin{array}{l}\text { Spirillospora rubra } \\
\text { JCM } 6875^{\mathrm{T}}\end{array}$ & 1 & 20 & 8 & 3 & 21 & 1 & 5 & 5 & 1 & $\mathrm{TR}$ & 5 & & 4 & 2 & & & & 1 & 2 & 11 & $\mathrm{a}$ \\
\hline (Actinomadura madurae) & 2 & 34 & 3 & 3 & 18 & 1 & 2 & 1 & & 1 & 20 & & 3 & & & & & TR & 3 & 9 & $\mathrm{c}$ \\
\hline (Actinomadura madurae) & 2 & 39 & 3 & 10 & 22 & 1 & 2 & 1 & & & 4 & & 1 & TR & & & & TR & 1 & 14 & $\mathrm{e}$ \\
\hline \multicolumn{22}{|c|}{ * Organisms in parentheses have been analysed previously. } \\
\hline
\end{tabular}


species except Actinomadura spadix in the 16S rDNA tree, though this separation is not clear in the $23 \mathrm{~S}$ rDNA tree due to unstable tree topology. Furthermore, the sequence similarity level of the $16 \mathrm{~S}-23 \mathrm{~S}$ spacers between these five species is much higher than between them and the rest of the Actinomadura species. In a re-examination of the phospholipid and wholecell sugar compositions, we detected major amounts of DPG, PE and PI in Actinomadura libanotica and the presence of madurose in Actinocorallia herbida. Thus, Actinomadura libanotica is characterized by phospholipid type PII, not PI, and Actinocorallia herbida has sugar type B, not type $\mathrm{C}$ as reported by Kroppenstedt et al. (1990) and Iinuma et al. (1994). Now all the five species of this clade are characterized by having phospholipid type PII, distinguishing them from all other Actinomadura species containing type PI phospholipids (Kroppenstedt, 1990; Iinuma et al., 1994; Itoh et al., 1995). Based on both phylogenetic and chemotaxonomic evidence, we propose the transfer of four Actinomadura species to the genus Actinocorallia: Actinomadura libanotica as Actinocorallia libanotica comb. nov., Actinomadura aurantiaca as Actinocorallia aurantiaca comb. nov., Actinomadura glomerata as Actinocorallia glomerata comb. nov. and Actinomadura longicatena as Actinocorallia longicatena comb. nov.

On the basis of 16S rDNA sequence analysis Stackebrandt et al. (1997) proposed the family Thermomonosporaceae, in which the genus Actinocorallia was not included. They also proposed the following nucleotide signatures to be characteristic of the members of Thermomonosporaceae: 440-494 (CG), 442-492 (G-C), four to seven extra bases between positions 453 and 479, 501-544 (C-G), 502-543 (G-C), 586-755 (C-G), 603-635 (U-A), 613-627 (C-G), 658-748 (C-U), 681-709 (C-G), 1003-1037 (A-G), 1116-1184 (C-G), 1355-1367 (A-U), 1422-1478 (G-C) and 1435-1466 (G-C). In all the Actinocorallia species we found all these nucleotide signatures except at 1003-1037 (G-C) and 1422-1478 (A-C). We also noticed that Thermomonospora curvata, Spirillospora species and a majority of Actinomadura species also have a G-C pair at 1003-1037; Actinomadura fulvescens and Actinomadura oligospora also have an A-C pair and Thermomonospora curvata has a G-T pair at 1422-1478. Thus, the initially proposed nucleotide signatures 1003-1037 (A-G) and 1422-1478 (G-C) should not be used as being characteristic of the members of Thermomonosporaceae. The rest of the nucleotide signatures for this family remain valid. Actinocorallia should be placed in the family Thermomonosporaceae.

Second, Excellospora viridilutea exhibits the closest relationship with Actinomadura rubrobrunea and they form a tight clade among other Actinomadura species in both the $16 \mathrm{~S}$ and $23 \mathrm{~S}$ rDNA trees. The levels of sequence similarity of all three DNA segments between the two species and other Actinomadura species are well within the range of similarity scores between
Actinomadura species. Therefore, there is neither a phylogenetic basis nor substantial chemotaxonomic differences to separate Excellospora viridilutea and Actinomadura rubrobrunea and to separate the two species from most Actinomadura species. We therefore propose the transfer of Excellospora viridilutea to the genus Actinomadura as Actinomadura viridilutea comb. nov.

Third, Spirillospora rubra is distantly related to Spirillospora albida and Spirillospora strain JCM $3123^{\mathrm{T}}$ as well as to all other species in the family Thermomonosporaceae, suggesting that Spirillospora rubra may merit an independent genus status. Spirillospora albida is shown to be very closely related to some Actinomadura species. The high level of sequence similarity, especially between the 16S-23S rDNA spacers (above $70 \%$ ) of Spirillospora albida and some Actinomadura species is particularly strong evidence for close relatedness. This level of similarity is significantly higher than most similarity values scored between different Actinomadura species. The phylogenetic data strongly suggest that Spirillospora albida has a very close evolutionary relationship with some Actinomadura species. So, should the two genera Spirillospora and Actinomadura be combined? It is still quite puzzling how Spirillospora species have developed complex sporangia containing motile spores, a property not found in any Actinomadura species. One explanation could be the lateral transfer (Lawrence \& Ochman, 1998) from a distant source of a whole cluster of genes required for producing the unique morphology into the ancestor of Spirillospora. If this is the case, the morphological distinction should not be translated into a distant organismal relationship and the two genera may need to be combined. However, currently there is no evidence supporting this hypothesis. Further studies are needed to unravel the relationships between Spirillospora and Actinomadura species.

Fourth, Actinomadura echinospora and Actinomadura umbrina have been shown to form a clade with Thermomonospora curvata, which is separated from other Actinomadura species in both the 16S and 23S rDNA trees and supported by a significant bootstrap value in the latter. The result suggests close relatedness among these three species. However, further investigations are needed to find other taxonomic properties to unify these species.

Finally, Actinomadura spadix may merit an independent genus status. The results of a previous numerical study (Athalye et al., 1985) and an electrophoretic mobility study of ribosomal protein AT-L30 (Ochi et al., 1991) of Actinomadura-related actinomycetes also suggested a distant relationship between Actinomadura spadix and other Actinomadura species.

As the result of the proposed transfers above, the family Thermomonosporaceae now embraces four genera Thermomonospora, Actinomadura, Spirillospora and Actinocorallia. 


\section{Emendation of Actinocorallia (linuma et al., 1994)}

The description is taken from Iinuma et al. (1994), Lavrova \& Preobrazhenskaya (1975), Meyer (1989), Kroppenstedt et al. (1990), Kudo (1997), Zhang et al. (1998) and this study. This genus is well defined on the basis of $16 \mathrm{~S}$ and $23 \mathrm{~S}$ rDNA sequence-based phylogenetic analyses and major chemotaxonomic properties, but exhibits some heterogeneity in morphological characteristics. Two species, Actinocorallia herbida and Actinocorallia libanotica, form synnemata bearing long chains of non-motile spores on their tips, while other species grow spore chains from aerial mycelium. Gram-positive and aerobic. Vegetative mycelia are branched but not fragmented. Mycolic acid is absent. All species are characterized by cell wall type III/B, phospholipid type PII, predominant menaquinones MK-9 $\left(\mathrm{H}_{4}\right)$, MK-9 $\left(\mathrm{H}_{6}\right)$ and MK-9 $\left(\mathrm{H}_{8}\right)$, and fatty acid type 3a. The type species is Actinocorallia herbida and the type strain is IFO $15485^{\mathrm{T}}\left(=\mathrm{JCM} 9647^{\mathrm{T}}\right)$.

\section{Description of Actinocorallia aurantica (Lavrova \& Preobrazhenskaya 1975) comb. nov.}

The description of Actinocorallia aurantica (Actinomadura Lavrova \& Preobrazhenskaya 1975) is similar to that given by Lavrova \& Preobrazhenskaya (1975) for phenotypic characteristics, by Kroppenstedt et al. (1990) for chemotaxonomic properties and by Zhang et al. (1998) and this study for its phylogenetic position. Type strain is $\mathrm{JCM} 8201^{\mathrm{T}}$.

\section{Description of Actinocorallia glomerata (Itoh et al., 1995) comb. nov.}

The description of Actinocorallia glomerata (Actinomadura Itoh et al., 1995) is the same as that given by Itoh et al. (1995) for phenotypic characteristics and chemotaxonomic properties, and by this study for its phylogenetic position. Type strain is $\mathrm{JCM} 9376^{\mathrm{T}}$.

\section{Description of Actinocorallia libanotica (Meyer 1979) comb. nov.}

The description of Actinocorallia libanotica (Actinomadura Meyer 1979) is the same as that given by Meyer (1989) and Kudo (1997) for phenotypic characteristics, by Kroppenstedt et al. (1990) and this study for chemotaxonomic properties and by Zhang et al. (1998) and this study for its phylogenetic position. Type strain is IFO $14095^{\mathrm{T}}$.

\section{Description of Actinocorallia longicatena (Itoh et al., 1995) comb. nov.}

The description of Actinocorallia longicatena (Actinomadura Itoh et al., 1995) is the same as that given by Itoh et al. (1995) for phenotypic characteristics and chemotaxonomic properties, and by this study for its phylogenetic position. Type strain is JCM $9377^{\mathrm{T}}$.

\section{Description of Actinomadura viridilutea (Agre and} Guzeva 1975) comb. nov.

The description of Actinomadura viridilutea (Excellospora Agre and Guzeva 1975) is the same as that given by Agre \& Guzeva (1975) for phenotypic characteristics, by Kroppenstedt \& Goodfellow (1992) for chemotaxonomic properties and by Zhang et al. (1998) and this study for its phylogenetic position. Type strain is $\mathrm{JCM} 3398^{\mathrm{T}}$.

\section{Emendation of the family Thermomonosporaceae (Stackebrandt et al., 1997)}

The following descriptions are taken from earlier investigations (Henssen, 1957; Couch, 1963; McCarthy \& Cross, 1984; Vobis \& Kothe, 1989; Meyer, 1989; Kroppenstedt et al., 1990; Goodfellow, 1992; Kroppenstedt \& Goodfellow, 1992; Iinuma et al., 1994; Kudo, 1997; Stackebrandt et al., 1997; Zhang et al., 1998) and this study. After the reclassification proposed by Zhang et al. (1998) and this paper, Thermomonosporaceae contains four genera, Thermomonospora, Actinomadura, Actinocorallia and Spirillospora. They form a distinct clade in the suborder Streptosporangineae and are closely related to the members of Streptosporangiaceae and Nocardiopsiaceae. All species of Thermomonosporaceae share the same cell wall type (type III; meso-diaminopimelic acid), a similar menaquinone profile [4B2; MK-9 $\left(\mathrm{H}_{4}\right)$, MK-9 $\left(\mathrm{H}_{6}\right)$ and MK-9 $\left.\left(\mathrm{H}_{8}\right)\right]$, in which MK-9( $\left.\mathrm{H}_{6}\right)$ is predominant, and fatty acid profile type $3 \mathrm{a}$, differentiating them from members of Streptosporangiaceae and Nocardiopsiaceae. The presentation of the diagnostic sugar madurose is variable, but can be found in most species of this family. The polar lipid profiles are characterized as phospholipid type PI by the presence of PIM, PI, PG and DPG for most species of Thermomonospora, Actinomadura and Spirillospora. The members of Actinocorallia are characterized by phospholipid type PII because of the presence of PE. Aerobic, Gram-positive, non-acid-fast, chemo-organotrophic actinomycetes which produce a branched substrate mycelium bearing aerial hyphae that undergo differentiation into single or short chains of arthrospores to sporangia containing the zoospores. The $\mathrm{G}+\mathrm{C}$ content of the DNA lies within the range 66-72 $\mathrm{mol} \%$. The pattern of $16 \mathrm{~S}$ rDNA signatures consists of nucleotides at positions 440-494 (C-G), 442-492 (G-C), four to seven extra bases between positions 453 and 479, 501-544 (C-G), 502-543 (G-C), 586-755 (C-G), 603-635 (U-A), 613-627 (C-G), 658748 (C-U), 681-709 (C-G), 1116-1184 (C-G), 13551367 (A-U) and 1435-1466 (G-C). The type genus is Thermomonospora (Henssen 1957).

\section{ACKNOWLEDGEMENTS}

This work was supported by the Institute of Molecular and Cell Biology, National University of Singapore. We thank Shinji Miyadoh for generously providing some unpublished information and suggestions through the whole course of 
this study and his critical reading of the manuscript. We also thank Alice Tay for DNA sequence analysis.

\section{REFERENCES}

Agre, N. S. \& Guzeva, L. N. (1975). New genus of the actinomycetes Excellospora gen. nov. Mikrobiologiya 44, 518-522 (in Russian).

Amann, R. I., Ludwig, W. \& Schleifer, K.-H. (1995). Phylogenetic identification and in situ detection of individual microbial cells without cultivation. Microbiol Rev 59, 143-169.

Athalye, M., Goodfellow, M., Lacey, J. \& White, R. P. (1985). Numerical classification of Actinomadura and Nocardiopsis. Int $J$ Syst Bacteriol 35, 86-98.

Atlas, R. M. (1993). In Hand book of Microbiological Medium. Edited by L. C. Parks. Boca Raton, FL: CRC Press.

Brosius, J., Palmer, M. L., Kennedy, P. J. \& Noller, H. F. (1978). Complete nucleotide sequence of a $16 \mathrm{~S}$ ribosomal RNA gene from Escherichia coli. Proc Natl Acad Sci U S A 75, 4801-4805.

Clayton, R. A., Sutton, G., Hinkle, P. S., Jr, Bult, C. \& Fields, C. (1995). Intraspecific variation in small-subunit rRNA sequences in GenBank: why single sequences may not adequately represent prokaryotic taxa. Int J Syst Bacteriol 45, 595-599.

Couch, J. N. (1963). Some new genera and family of the Actinoplanaceae. J Elisha Mitchell Sci Soc 79, 53-70.

Felsenstein, J. (1985). Confidence limits on phylogenies: an approach using the bootstrap. Evolution 39, 783-791.

Goodfellow, M. (1992). The family Streptosporangiaceae. In The Prokaryotes, 2nd edn, pp. 1116-1138. Edited by A. Balows, H. G. Trüper, M. Dworkin, W. Harder \& K.-H. Schleifer. New York: Springer.

Greiner-Mai, E., Kroppenstedt, R. M., Korn-Wendisch, F. \& Kutzner, H. J. (1987). Morphological and biochemical characterization and amended descriptions of thermophilic actinomycetes species. Syst Appl Microbiol 9, 97-109.

Gurtler, V. \& Stanisich, V. A. (1996). New approaches to typing and identification of bacteria using the $16 \mathrm{~S}-23 \mathrm{~S}$ rDNA spacer region. Microbiology 142, 3-16.

Gutell, R. G., Larson, N. \& Woese, C. R. (1994). Lessons from an evolving rRNA: $16 \mathrm{~S}$ and $23 \mathrm{~S}$ rRNA structures from a comparative perspective. Microbiol Rev 58, 10-26.

Henssen, A. (1957). Beitrage zur Morphologie und systematic der thermophilen actinomyceten. Arch Mikrobiol 26, 373-414.

Higgins, D. G., Bleasby, A. J. \& Fuchs, R. (1992). CLUSTAL V: improved software for multiple sequence alignment. Comput Appl Biosci 8, 189-191.

Holt, J. G., Krieg, N. R., Sneath, P. H. A., Staley, J. T. \& Williams, S. T. (1994). Bergey's Manual of Determinative Bacteriology, 9th edn, pp. 690-691. Baltimore: Williams \& Wilkins.

linuma, S., Yokota, A., Hasegawa, T. \& Kanamaru, T. (1994). Actinocorallia gen. nov., a new genus of the order Actinomycetales. Int J Syst Bacteriol 44, 230-234.

Itoh, T., Kudo, T., Oyaizu, H. \& Seino, A. (1995). Two new species in the genus Actinomadura: A. glomerata sp. nov., and $A$. longicatena sp. nov. Actinomycetology 9, 164-177.

Jukes, T. H. \& Cantor, C. R. (1969). Evolution of protein molecules. In Mammalian Protein Metabolism, pp. 21-132. Edited by H. N. Munro. New York: Academic Press.
Kroppenstedt, R. M. \& Goodfellow, M. (1992). The family Thermomonosporaceae. In The Prokaryotes, 2nd edn, pp. 1085-1114. Edited by A. Balows, H. G. Trüper, M. Dworkin, W. Harder \& K.-H Schleifer. New York: Springer.

Kroppenstedt, R. M., Stackebrandt, E. \& Goodfellow, M. (1990). Taxonomic revision of the actinomycete genera Actinomadura and Microtetraspora. Syst Appl Microbiol 13, 148-160.

Kudo, T. (1997). Family Thermomonosporaceae. In Atlas of Actinomycetes, pp. 82-100. Edited by S. Miyadoh. Tokyo: Asakura Publishing.

Kudo, T., Itoh, T., Miyadoh, S., Shomura, T. \& Seino, A. (1993). Herbidospora gen. nov., a new genus of the family Streptosporangiaceae Goodfellow et al. 1990. Int J Syst Bacteriol 43, 319-328.

Lavrova, N. V. \& Preobrazhenskaya, T. P. (1975). Isolation of new species of Actinomadura on selective media with rubomycin. Antibiotiki 20, 483-488 (in Russian).

Lechevalier, M. P. \& Lechevalier, H. (1970). Chemical composition as a criterion in the classification of aerobic actinomycetes. Int J Syst Bacteriol 20, 435-443.

Lawrence, J. G. \& Ochman, H. (1998). Molecular archaeology of the Escherichia coli genome. Proc Natl Acad Sci USA 95, 9413-9417.

McCarthy, A. J. \& Cross, T. (1984). A taxonomic study of Thermomonospora and other monosporic actinomycetes. J Gen Microbiol 130, 5-25.

Meyer, J. (1979). New species of the genus Actinomadura. Z Allg Mikrobiol 19, 37-44.

Meyer, J. (1989). Genus Actinomadura Lechevalier \& Lechevalier (1970). In Bergey's Manual of Systematic Bacteriology, vol. 4, pp. 2511-2526. Edited by S. T. Williams, M. E. Sharpe \& J. G. Holt. Baltimore: Williams \& Wilkins.

Mikami, H. \& Ishida, Y. (1983). Post-column fluorometric detection of reducing sugars in high-performance liquid chromatography using arginine. Bunseki Kagaku 32, E207-E210.

Minnikin, D. E., O'Donnell, A. G., Goodfellow, M., Alderson, G., Athalye, M., Schaal, A. \& Parlett, J. H. (1984). An integrated procedure for the extraction of bacterial isoprenoid quinones and polar lipids. J Microbiol Methods 2, 233-241.

Ochi, K., Miyadoh, S. \& Tamura, T. (1991). Polyacrylamide gel electrophoresis analysis of ribosomal protein AT-L30 as a novel approach to actinomycete taxonomy: application to the genera Actinomadura and Microtetraspora. Int J Syst Bacteriol 41, 234-239.

Saitou, N. \& Nei, M. (1987). The neighbor-joining method: a new method for reconstructing phylogenetic trees. Mol Biol Evol 4, 406-425.

Skerman, V. B. D., McGowan, V. \& Sneath, P. H. A. (1980). Approved lists of bacterial names. Int J Syst Bacteriol 30, 225-420.

Stackebrandt, E. \& Goebel, B. M. (1994). Taxonomic note: a place for DNA-DNA reassociation and 16S rRNA sequence analysis in the present species definition in bacteriology. Int $J$ Syst Bacteriol 44, 846-849.

Stackebrandt, E., Rainey, F. A. \& Ward-Rainey, N. L. (1997). Proposal for a new hierarchic classification system, Actinobacteria classis nov. Int J Syst Bacteriol 47, 479-491.

Suzuki, K. \& Komagata, K. (1983). Taxonomic significance of cellular fatty acid composition in some coryneform bacteria. Int J Syst Bacteriol 33, 188-200. 
Swofford, D. L. \& Begle, D. P. (1993). Phylogenetic Analysis Using Parsimony, version 3.1, User's Manual. Smithsonia, Champaign, IL: Laboratory of Molecular Systematics.

Vobis, G. \& Kothe, H-W. (1989). Genus Spirillospora Couch 1963 , $61^{\mathrm{AL}}$. In Bergey's Manual of Systematic Bacteriology, vol. 4, pp. 2543-2545. Edited by S. T. Williams, M. E. Sharpe \& J. G. Holt. Baltimore: Williams \& Wilkins.

Wang, Y., Zhang, Z. S. \& Ruan, J. S. (1996). Phylogenetic analysis reveals new relationships among members of the genera Microtetraspora and Microbispora. Int J Syst Bacteriol 46, 658-663.

Wang, Y., Zhang, Z. S. \& Narendrakumar, R. (1997). The actinomycete Thermobispora bispora contains two distinct types of transcriptionally active $16 \mathrm{~S}$ rRNA genes. J Bacteriol 179, $3270-3276$.
Woese, C. R. (1987). Bacterial evolution. Microbiol Rev 51, 221-271.

Woese, C. R., Kandler, O. \& Wheelis, M. L. (1990). Towards a natural system of organisms: proposal for the domains Archaea, Bacteria and Eucarya. Proc Natl Acad Sci U S A 87, 4576-4579.

Yap, W. H., Zhang, Z. S. \& Wang, Y. (1999). Distinct types of rRNA operons exist in the genome of the actinomycete Thermomonospora chromogena and evidence for horizontal transfer of an entire rRNA operon. J Bacteriol 181, 5201-5209.

Zhang, Z. S., Wang, Y. \& Ruan, J. S. (1997). A proposal to revive the genus Kitasatospora (Omura, Takahashi, Iwai and Tanaka, 1982). Int J Syst Bacteriol 47, 1048-1054.

Zhang, Z. S., Wang, Y. \& Ruan, J. S. (1998). Reclassification of Thermomonospora and Microtetraspora. Int J Syst Bacteriol 48, 411-422. 